\title{
Use of local Hydromacrophytes as phytoremediation agent in pond to improve irrigation water quality evaluated by Diatom Biotic Indices
}

\author{
CATUR RETNANINGDYAH ${ }^{\boldsymbol{\nu}}$, ENDANG ARISOESILANINGSIH, SETIJONO SAMINO \\ Department of Biology, Faculty of Mathematics and Natural Sciences, Universitas Brawijaya. Jl. Veteran, Malang 65145, Jawa Timur, Indonesia. \\ Tel./Fax: +62-341-575840 Fax: +62-341-554403, ”email: caturretnaningdyah@gmail.com
}

Manuscript received: 29 April 2017. Revision accepted: 14 October 2017

\begin{abstract}
Retnaningdyah C, Arisoesilaningsih E, Samino S. 2017. Use of local Hydromacrophytes as phytoremediation agent in pond to improve irrigation water quality evaluated by Diatom Biotic Indices. Biodiversitas 18: 1596-1602. Irrigation water in Indonesia generally has been polluted because of agricultural, industrial and domestic activity. The aims of this research were to determine the effectiveness of phytoremediation models conducted by planting some local Hydromacrophytes in three phytoremediation ponds through a continuous culture system with water discharge about $0.3 \mathrm{~L} / \mathrm{seconds}$ for improving the irrigation water quality. The quasiexperimental research was conducted in a phytoremediation pond located in Kepanjen District of Malang, East Java Indonesia. The phytoremediation pond was divided into four interconnected sections. Pond 1 and 2 were planted with some of floating leaf and emergent hydromacrophyte, pond 3 was planted by combinations of same plants added with submerged Hydromacrophytes, while pond 4 was container pond to collecting the water as a result of phytoremediation process. The success of phytoremediation process was known from some physico-chemical parameters of water and some of diatom biotic indices (trophic diatom index/TDI, percentage of pollution tolerant value (\%PTV), and Shannon Wiener diversity Index) that was found from artificial substrate been installed in the early treatment. The water quality monitoring performed in each part of the ponds after the plants grew steadily. The results showed that planting of Hydromacrophytes can significantly improve the physico-chemical quality of water. This was reflected in the decline value of conductivity (from $188 \mu \mathrm{S} / \mathrm{cm}$ to $182 \mu \mathrm{S} / \mathrm{cm}$ ), turbidity (30 NTU become $8 \mathrm{NTU}$ ), total suspended solid (TSS) from $31.3 \mathrm{mg} / \mathrm{L}$ to be $5.5 \mathrm{mg} / \mathrm{L}$, nitrates $(7.5 \mathrm{mg} / \mathrm{L}$ to $3.3 \mathrm{mg} / \mathrm{L}$ ) and dissolved phosphates (from $0.16 \mathrm{mg}$./L become $0.04 \mathrm{mg} / \mathrm{L}$ ) and increasing value of dissolved oxygen (DO) in waters from $2.6 \mathrm{mg} / \mathrm{L}$ become $2.9 \mathrm{mg} / \mathrm{L}$. Based on biotic indices there were improvement of the water quality from heavily polluted (diversity index 0.91) become moderately polluted (diversity index 2.07), eutrophic (TDI 52) become mesoeutrophic (TDI 38), and from heavily organic pollution (PTV 93\%) to be some organic pollution contribute to eutrophication (PTV $38 \%$ ). Improvement of water quality was effectively occur after passing through the third pond.
\end{abstract}

Keywords: Diatom biotic indices, local Hydromacrophytes, phytoremediation pond, water quality

\section{INTRODUCTION}

Phytoremediation is an alternative new technology to clean up the pollution in the environment that utilizes abilities of plants. The plants can work together with microbes to convert pollutants in the media (soil, coral, water) into less or not harmful substances (EPA, 2000; Etim, 2012). Irrigation water in Indonesia has been polluted because of human activity especially agriculture. Some synthetic fertilizers have been used by farmers in agricultural practice that increase the nutrient element such as nitrogen $(\mathrm{N})$, phosphorous $(\mathrm{P})$ and potassium or kalium $(\mathrm{K})$. This residue will cause a negative impact on the environment. Contamination of residual nitrogen and phosphorous from agricultural activity was higher than produced by industrial or domestic activities (Panagopoulos et al. 2007; Yang et al. 2007; Yin et al. 2007). It will trigger eutrophication in the water ecosystem.

The eutrophication process can be controlled by increasing the absorption and uptake by hydrophytes, microbes and denitrification process (Saunders and Kalff 2001; Sybil et al. 2002; Marcus and Kŏhler 2006; Chen et al. 2010; Retnaningdyah et al. 2009). Hydrophytes and riparian vegetation in the irrigation channels could play a significant role in reducing eutrophication risk and also could promote degradation of toxic residual pesticides accumulated from agriculture ecosystem (Chaudhry et al. 2002).

The result of previous research in laboratory experiments using batch culture systems have proved that some Hydromacrophytes such as Azolla sp., Hydrilla verticillata, Limnocharis flava, Marsilea crenata, Equisetum ramosissium, Typha angustifolia, Scirpus grossus and Lymnocharis flava in monoculture or polyculture showed high potential as a remediator agent of nitrate and phosphate in aquatic ecosystem (Retnaningdyah and Suharjono 2010; Vidayanti et al. 2012; Sundari et al. 2012; Prahardika et al. 2012). The success of phytoremediation process is determined by plant productivity. The productivity of Hydromacrophytes was influenced significantly by the type of Hydromacrophytes, availability of resources, environmental stress and its adaptability to the environment. Emergent Hydromacrophytes has highest productivity and respectively be followed by floating leaf and submerged plants. Environmental factors that affect species distribution and growth of plants in wetlands includes the depth and current velocity of water that correlates with the 
supply of oxygen, light and nutrient (Guntenspergen et al. 1989; Barko et al. 1982).

Based on these data, in order to apply this phytoremediation technique in the irrigation channels, it is necessary to determine the effectiveness of phytoremediation models conducted by planting some of local floating leaf, emergent and submerged Hydromacrophytes in phytoremediation pond through a continuous culture system for improving the irrigation water quality. The success of phytoremediation process can be evaluated by monitoring the water quality.

The evaluation method of water quality can be done partially or in combination with physico-chemical and biological methods. The benefit of using physico-chemical parameters for monitoring the quality of water is because it has a simple value and can be determined at any time, while the disadvantage is that these measures merely describe a moment circumstances and can not give an idea of the whole condition of ecosystems (John 1995). The investigation of the periphyton community as bioindicator has become an important part of water quality monitoring. Periphytons, more commonly known as aufwuchs or attached benthic algae, are groups of various organisms that grow or live on the free surface of objects that float and or sink in water such as plants, wood, stones and so on. Periphytons have been widely recommended to be used as bioindicators of water quality (Herbst \& Blinn, 2007; Mbao et al. 2013). The advantages of use of periphytons as a pollution indicators is due to their ubiquitous presence, relatively large number, ease of finding, collecting and identifying and also their rapid responses to environmental changes and degraded water quality (Tan et al. 2013). One of the periphyton groups often used as a bioindicator of water quality is the algae of the diatoms group (Roubeix et al. 2011). Indication of water quality using diatom as bioindicator can be seen from some biotic indices. Trophic diatom index (TDI), percentage pollution tolerant values
(\%PTV) and diversity index are some of biotic indices be use to indication the level of eutrophication, organic pollution and level of toxic pollution (Wu et al. 2014).

\section{MATERIALS AND METHODS}

\section{Research design}

The quasi-experimental research was conducted in situ in a phytoremediation pond located in Kepanjen District of Malang, East Java, Indonesia. Some of local Hydromacrophytes in the phytoremediation ponds were floating leaf macrophyte (Nymphaea sp.), emergent (Ipomoea crassicaulis, Ipomoea aquatica, Acorus calamus, Fimbristylis globulosus, Limnocharis flava, Scirpus grossus, Typha angustifolia, Ludwigia sp., Cyperus alternatifolius, Colocasia esculenta, Alternanthera sessilis, Pandanus amaryllifolius and Coix lacrima-jobi) and submerged Hydromacrophytes (Hydrilla verticillata, Valisneria gigantea, and Cryptocoryne sp.). The phytoremediation pond was divided into four interconnected sections restricted by partitions that served as dikes and were given a connecting pipe to drain water. Ponds 1 and 2 were planted with some of floating leaf and emergent Hydromacrophytes, while pond 3 was planted with combinations of the same plants which added with submerged Hydromacrophytes. Pond 4 was a container pond to collect the water as a result of phytoremediastion process (Figure 1). The planting of those Hydromacrophytes was done in each pond with area coverage started about $50 \%$ from the pond surface area. The Hydromacrophytes were maintained until about 3 months old, at which time plant coverage achieved $75-80 \%$ of the pond area. Then the experiment was done by using the continuous culture system methods with water discharge about $0.3 \mathrm{~L} /$ seconds.

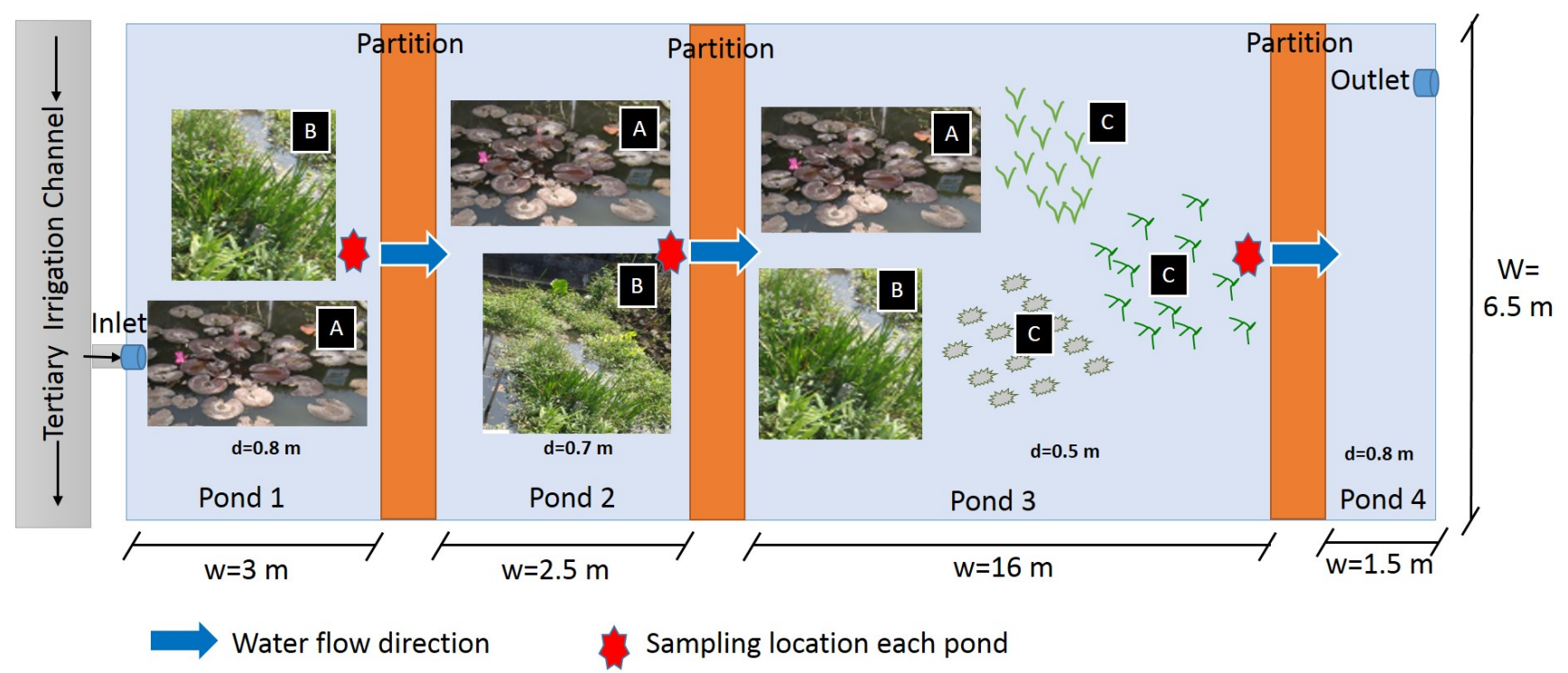

Figure 1. Pond phytoremediation model was used in this research. Note: $A=$ floating leaf Hydromacrophytes; $B=$ emergent Hydromacrophytes; $\mathrm{C}=$ submerged hydromarophytes; $\mathrm{w}=$ pond width; $\mathrm{d}=$ pond depth 
Table 1. Water physico-chemical parameters were measure in this research

\begin{tabular}{lll}
\hline Parameters & Unit & Methods \\
\hline Conductivity & $\mu \mathrm{S} / \mathrm{cm}$ & Conductivitymeter \\
Dissolved Oxygen (DO) & $\mathrm{mg} / \mathrm{L}$ & Digital Oxygenmeter \\
Turbidity & $\mathrm{NTU}$ & Turbidimeter \\
Nitrate & $\mathrm{mg} / \mathrm{L}$ & Brucine methods \\
Total Suspended Solid (TSS) & $\mathrm{mg} / \mathrm{L}$ & Gravimetric \\
Dissolved phosphates & $\mathrm{mg} / \mathrm{L}$ & Stannous chloride \\
(Orthophosphate) & & methods \\
\hline
\end{tabular}

\section{Monitoring water quality}

The success or effectiveness of the phytoremediation process was estimated from several physico-chemical parameters, diatom diversity index, trophic diatom index (TDI) and percentage pollution tolerant values (\%PTV). Those parameters were measured at the end of ponds 1 to 3 compared to the water in the tertiary irrigation drain (Figure 1). The physico-chemical parameters measured in this research included conductivity, dissolved oxygen (DO), turbidity, total suspended solid (TSS), nitrates and dissolved phosphates. Those parameters were determined based on Clesceri et al. (1998) as can be seen in Table 1. Diatoms were obtained from artificial substrate (ceramics $20 \times 20 \mathrm{~cm}^{2}$ ) that had been installed in early treatment together with the time planting of Hydromacrophytes. The monitoring of water quality and community structure of diatoms were performed in each part of the ponds after the plants grew steadily for about 3 months after which plant coverage achieved $75-80 \%$ of the pond area. Diatom identification was based on Edmondson (1959) and Prescott (1978).

\section{Data analyses}

The data from diatoms (density and taxa richness) were used to determined the Shannon Wiener diversity index based on the formula of $\mathrm{Wu}$ et al. (2014). Trophic diatom index (TDI) and the percentage pollution tolerant values (\%PTV) were based on Kelly and Whitton (1995) and Kelly (1998) as bioindicator of water quality in the ponds after phytoremediation process. The difference in water quality between the ponds were determined by Anova and followed by Tukey HSD test at the 0.05 level, performed with SPSS for Windows Release 16.

\section{RESULTS AND DISCUSSION}

\section{Physico-chemical quality}

Planting of some local floating leaf, submerged and emergent Hydromacrophytes over as much as $75-80 \%$ of the surface area in the phytoremediation ponds through a continuous culture system with discharge of irrigation water at aproximately $0.3 \mathrm{~L} / \mathrm{seconds}$ was able to improve the water quality as reflected in the increase of dissolved oxygen (DO) and a decrease in the concentration of nitrate, dissolved phosphate, total suspended solid (TSS), conductivity, and turbidity significantly, especially in the pond 3 (Figure 2).

This model of phytoremediation process was able to increase the levels of DO from $2.6 \mathrm{mg} / \mathrm{L}$ or $32 \%$ to 2.9 $\mathrm{mg} / \mathrm{L}$ or $3.4 \%$. This concentration meets the quality standard of water class IV for irrigation based on the provision of Indonesia government regulation No. 82 of 2001 on water quality management and water pollution control. The phytoremediation process also significantly decreased the water conductivity from $188 \mu \mathrm{S} / \mathrm{cm}$ to 182 $\mu \mathrm{S} / \mathrm{cm}$. The range of conductivity values are equivalent to $0.188-0.182 \mathrm{dS} / \mathrm{m}$ which already meets the irrigation water quality standards of FAO in the amount of 0.0-3.0 dS/m.

The phytoremediation process was able to significantly reduce the value of turbidity in the irrigation channel from $30 \mathrm{NTU}$ to $8 \mathrm{NTU}$ in the outlet of pond 3 . This showed that planting of Hydromacrophytes had an impact on the sedimentation process of suspended solid in irrigation water. Planting Hydromacrophytes has also reduced the levels of total suspended solid (TSS) significantly from $31.3 \mathrm{mg} / \mathrm{L}$ to $5.5 \mathrm{mg} / \mathrm{L}$ in the outlet of pond 3 . The value of TSS is in compliance with the quality standards of Class I (raw water drinking water) and II (water for recreation, fishery, animal husbandry and irrigation) based on Indonesia government regulation with a maximum limit of level $50 \mathrm{mg} / \mathrm{L}$.

The residue of synthetic fertilizers in irrigation water is reflected in the levels dissolved phosphate and nitrate. Planting of some local floating leaf, submerged and emergent Hydromacrophytes in phytoremediation ponds over as much as $75-80 \%$ of the pond surface area has been shown to significantly reduce levels of nitrates and phosphates dissolved in the water (Figure 2). Phytoremediation process has successfully decreased the levels of nitrates from $7.5 \mathrm{mg} / \mathrm{L}$ to $3.3 \mathrm{mg} / \mathrm{L}$. Similarly, levels of dissolved phosphates or orthophosphate decreased from $0.16 \mathrm{mg} / \mathrm{L}$ to $0.04 \mathrm{mg} / \mathrm{L}$. Concentration of nitrates between $5-30 \mathrm{mg} / \mathrm{L}$ indicates a slight to moderate degree of restriction on use, whereas the nitrate concentration of less than $5 \mathrm{mg} / \mathrm{L}$ indicated good quality and can be used for all agricultural crops. The quality standard of nitrate for recreation, fishery, animal husbandry and irrigation (Class II) based on Indonesia government regulation No. 82/2001 is $10 \mathrm{mg} / \mathrm{L}$.

\section{Diatom biotic indices}

Improvement of water quality in the phytoremediation pond using some local of Hydromacrophytes can be seen from the decreasing value of some water physico-chemical parameters and it can also be seen from the diatom biotic indices as bioindicator of water quality. In this study, together with the planting of Hydromacrophytes, we were also installed the artificial substrate of diatoms from ceramics $20 \times 20 \mathrm{~cm}^{2}$. We then monitored those diatom diversity in the same time as water physico-chemical measurements. 

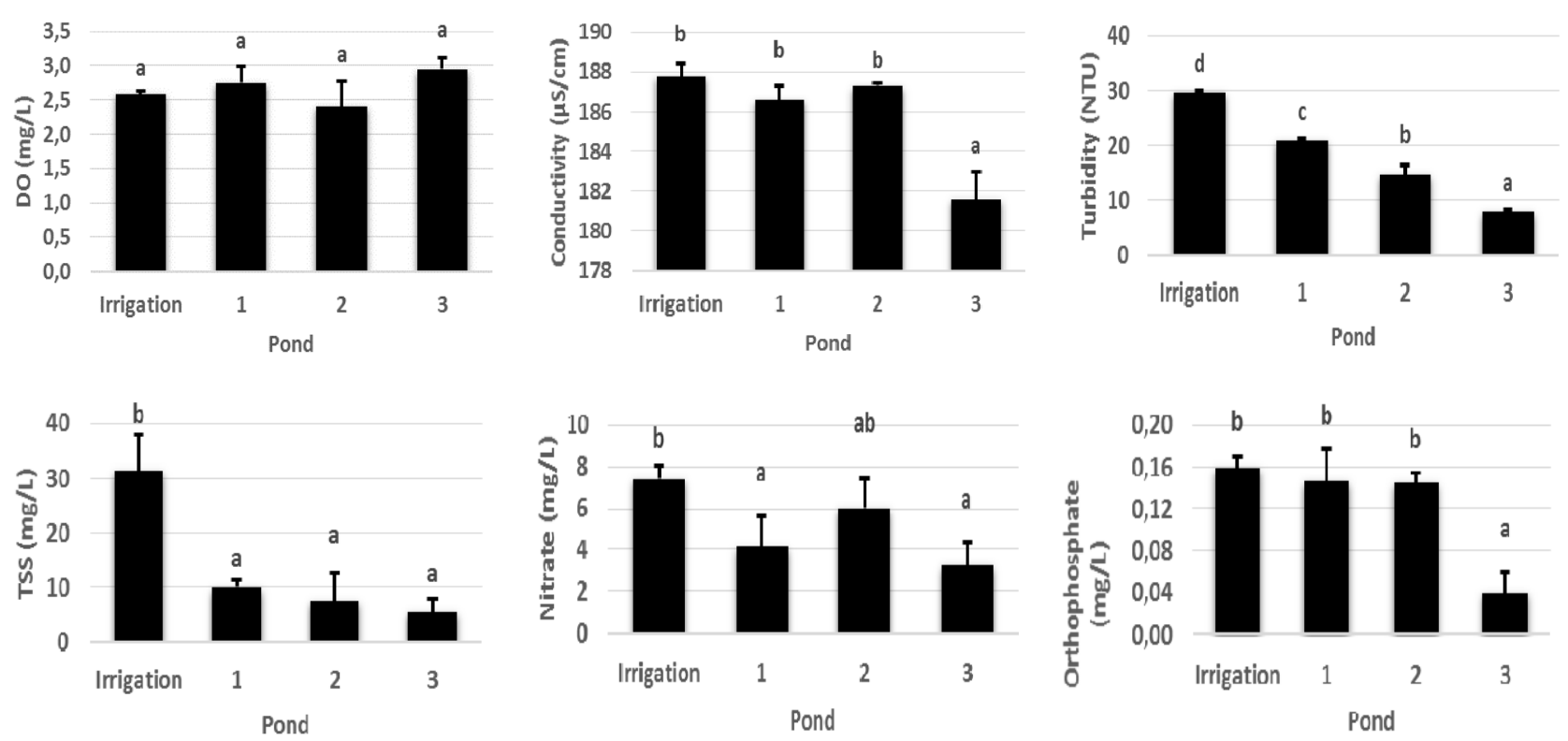

Figure 2. The average value of dissolved oxygen (DO), conductivity, turbidity, total suspended solid (TSS), nitrates and dissolved phosphates (orthophosphates) water in irrigation drain compared with three ponds after phytoremedation process through continuous culture system with discharge of irrigation water $0.3 \mathrm{~L} /$ seconds using some local floating leaf, submerged and emergent Hydromacrophytes over as much as $75-80 \%$ of the pond surface area. Note: The same notation (a,b,c,d) on each parameter showed no significant difference by ANOVA test followed by Tukey HSD $\alpha 0.05$

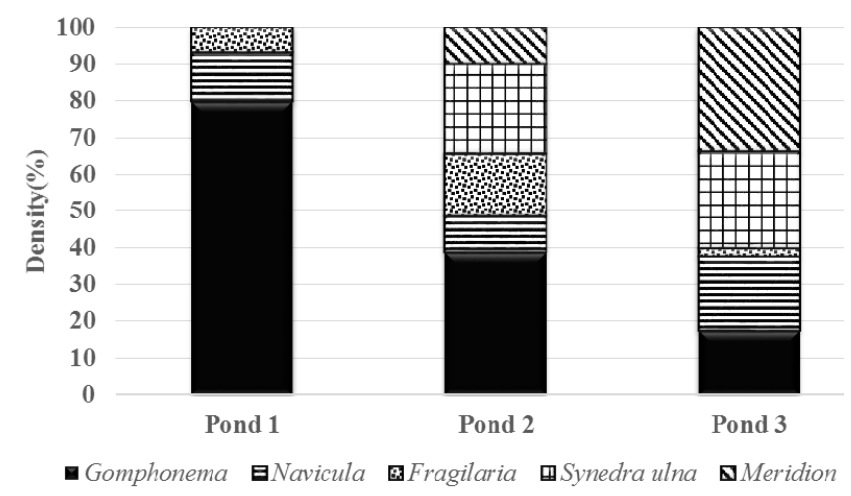

Figure 3. Taxa richness and relative density of diatom in ponds after phytoremedation process

Diatoms taxa richness tended to be higher at second and third ponds than in the pond 1. Taxa richness increased from three species in pond 1 to five species in the ponds 2 and 3 (Figure 3). The water quality improved after the phytoremediation process in all three ponds. This can be seen from the Shannon Wiener diversity index (Figure 4.A) that increased from 0.91 (heavily polluted) to 2.12 and 2.07 (moderately polluted). Similarly, based on the value of trophic diatom index/TDI (Figure 4.B) the status of water changed from eutrophic (TDI=52) to meso eutrophic
$(\mathrm{TDI}=38)$ in pond 3 . Based on the organic pollution level which can be indicated by the percentage of pollution tolerant values/\%PTV (Figure 4.C), the process of phytoremediation increased the quality of water from heavily organic pollution ( $\mathrm{PTV}=93.3 \%$ ) to some organic pollution contribute to eutrophication $(\mathrm{PTV}=37.8 \%)$.

The effectiveness of the phytoremediation process in three phytoremediation ponds through a continuous culture system planted by some local Hydromacrophytes can be seen from increasing the water quality in the outlet of third pond. This could be shown by differences of some parameters of physico-chemical and diatom biotic indices between pond 1 and 2 with pond 3. Based on cluster and biplot analyses (Figure 5), it can be concluded that the phytoremediation model used in this research was successfull in improving the irrigation water quality. This can be seen from the significant differences in water quality between outlet of first pond and outlet of second and third pond. Some parameters in pond 1 such as total suspended solid (TSS), turbidity, trophic diatom index (TDI) and percentage of pollution tolerant value (\%PTV) significantly higher than in pond 2 and 3. This indicated that pond 1 had eutrophic water with heavily organic pollution. While all levels of physico-chemical parameters observed in pond 3 were significantly lower except dissolved oxygen (DO) and Shannon Wiener diversity index of diatom $(\mathrm{H})$ which indicates the improvement status of the waters of this pond become meso-eutrophic with some organic pollution contribute to eutrophication. 


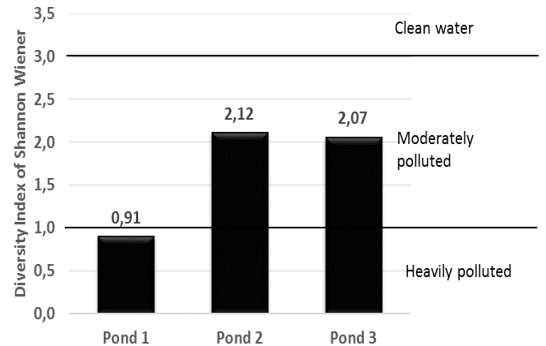

A

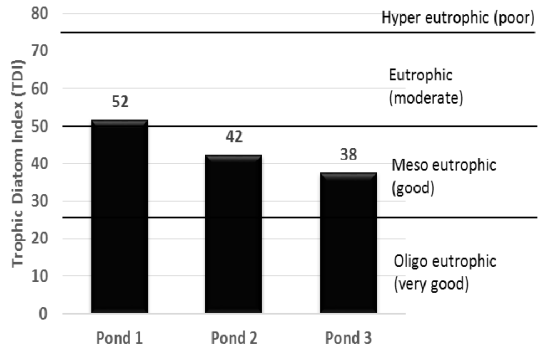

B

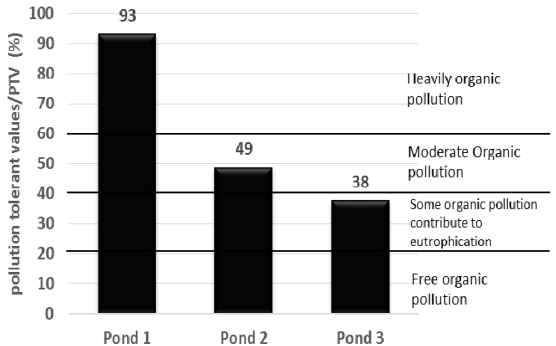

C

Figure 4. Shannon Wiener Diversity Index (A), Trophic Diatom Index/TDI (B) and Percentage of Pollution Tolerant Value/\%PTV (C) of diatom be found in the three phytoremediation pond

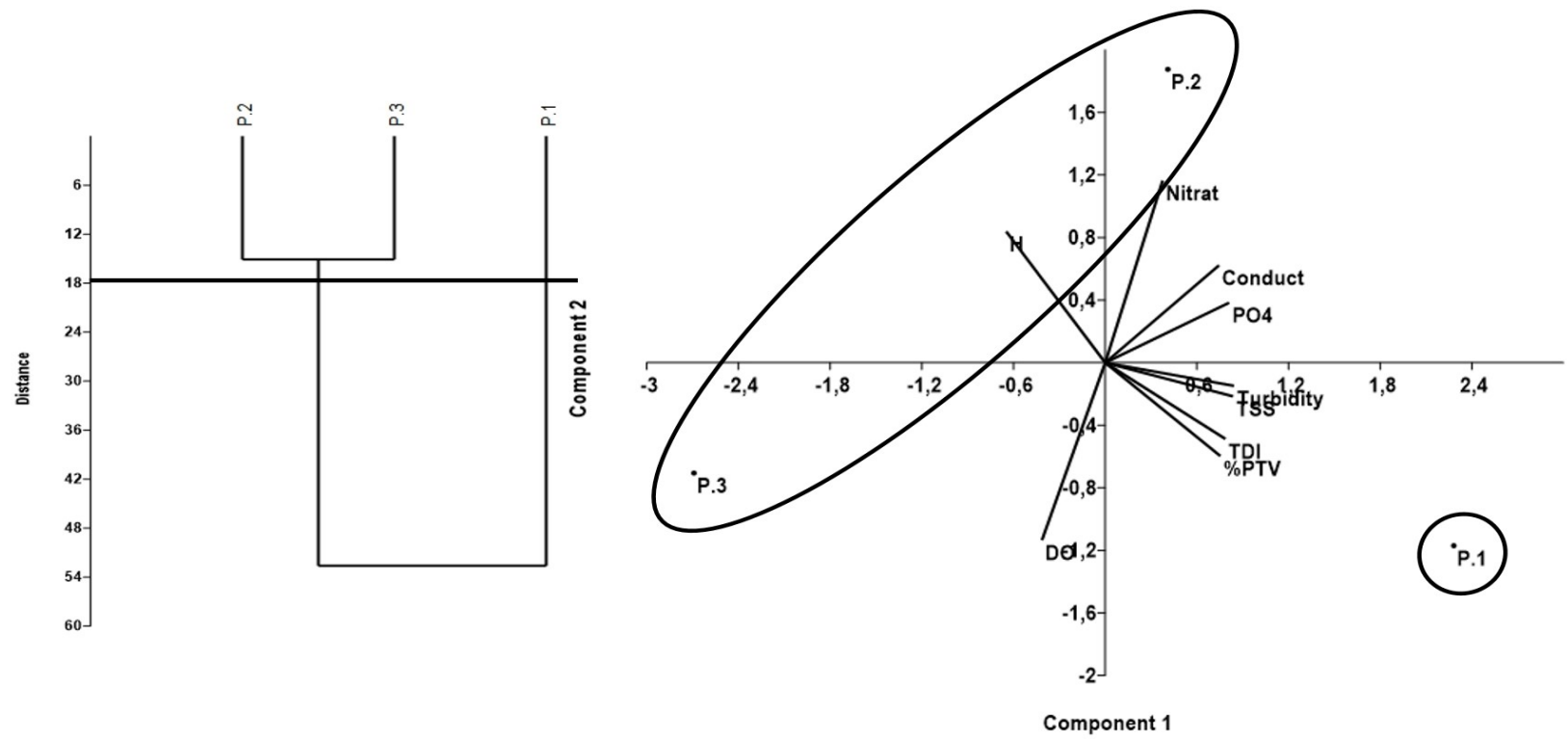

Figure 5. Grouping the quality of water in the pond (P) after phytoremedation process based on some physico-chemical parameters and diatom biotic indices using cluster analyses and biplot from principle component analyses (PCA). Note: P.1= pond 1; P.2= pond 2; P.3= pond 3; $\mathrm{H}=$ Shannon Wiener diversity index of diatom; TDI= Trophic Diatom Index; \%PTV= Percentage of Pollution Tolerant Value; TSS=total suspended solid; PO4= dissolved phosphate/orthophosphate; Conduct= conductivity

\section{Discussion}

The results of this research showed that the water quality characteristics of irrigation drains have are contaminated, reflected by the high values of turbidity, conductivity, total suspended solid (TSS), nitrate and dissolved phosphates (orthophosphate) and low levels of dissolved oxygen (DO). Process of phytoremediation in three ponds were planted with various kinds of local floating leaf, submerged and emergent Hydromacrophytes over as much as $75-80 \%$ of the surface area in ponds through a continuous culture system with discharge of irrigation water of aproximately $0.3 \mathrm{~L} / \mathrm{seconds}$ can significantly improve the water quality. Conductivity and dissolved phosphate levels in irrigation canals were high and were lower in third ponds after passing the first and second pond. The phytoremediation pond 1 and 2 were able to decrease the value of turbidity, total suspended solid (TSS) and nitrates in the irrigation water into a medium level and the levels of these parameters becomes significantly low after pass the third pond of phytoremediation (Figure 2).

The results of our research is in accordance with the results of others. Hydromacrophytes acts as a filter sediment, phosphorus and dissolved nitrogen so then can generally improve the quality of water (Jayaweera and Kasturiarachchi 2004; Xiang et al. 2009). Some Hydromacrophytes such as Hydrilla verticillata, Marsilea crenata, Scirpus grossus, Limnocharis flava, Fimbristylis globulosa, Vetiveria zizanoides, Equisetum ramosissium, Typha angustifolia, Azolla sp., Monochoria vaginalis, 
Ludwigia hyssopifolia, and Ludwigia adscendens have also been proven to reduce pollutants of dissolved nirogen and dissolved phosphate derived from synthetic fertilizer and other materials on the scale of the greenhouse through a batch culture system (Jayaweera dan Kasturiarachchi 2004; Xiang et al. 2009; Retnaningdyah et al. 2012; Vidayanti et al. 2012; Retnaningdyah and Arisoesilaningsih 2013; Prahardika et al. 2013; Sundari et al 2013; Ivansyah and Retnaningdyah 2013).

Hydromacrophytes were used for phytoremediation process on third pond in this research is combination of floating leaf, emergent as in first and second pond with more abundance. Besides that, in the third pond was also enhanced with submerged Hydromacrophytes having advantages which is oxygen as a result of photosynthesis directly dissolved in water so that dissolved oxygen levels in the pond three is always the highest (averaged $2.9 \mathrm{mg} / \mathrm{L}$ ) compared with the levels of oxygen of the others. This value has fulfilled the quality standards expected by Indonesia government regulation No. 82/2001 Class IV. However, the increasing value of dissolved oxygen still need to be done by determining a proper water retention time in the phytoremediation process of continuous culture system pond.

Planting of some local floating leaf, submerged and emergent Hydromacrophytes over as much as $75-80 \%$ of the surface area in phytoremediation ponds through a continuous culture system with discharge of irrigation water of aproximately $0.3 \mathrm{~L} /$ seconds in this study has successfully reduced water conductivity from $0.188 \mathrm{dS} / \mathrm{m}$ to $0.182 \mathrm{dS} / \mathrm{m}$. Conductivity values can be used to determine the concentration of dissolved salt or salinity in the water which further will determine the availability of water for crops. Conductivity values may reflect the presence or absence of salinity problems or levels of dissolved salts conditions that affect agricultural crops (Ayers and Westcot 1994). Conductivity values less than $0.7 \mathrm{dS} / \mathrm{m}$ indicating no problems of salinity in irrigation water so that it can be used for all agricultural crops without restrictions.

Improvement of water quality after the phytoremediation process in three ponds using some local floating, emergent and submerged Hydromacrophytes besides may decrease some value of physico-chemical parameters, can also be seen from the diversity of diatoms. Results of monitoring the diatom diversity in an artificial substrate showed that the taxa richness increase from three taxa in the pond 1 to five taxa in the pond 3. Based on the calculations of density, there was a decreasing relative abundance of Gomphonema sp. from $80 \%$ in first pond to $18 \%$ in the third pond. According to Kelly and Whitton (1995), Gomphonema sp. is a tolerant species toward organic pollution, while based Onyema (2013) and Singh et al. (2013) Gomphonema sp. was a kind of bioindicator of high nutrient levels (eutrophic) and organic pollution in the water. Improvement of water quality as a result of phytoremediation process in this study also was reflected by Shannon Wiener diversity index $(\mathrm{H})$ which categorized from heavily polluted in the first pond $(\mathrm{H}=0.91)$ become moderately polluted in the third pond $(\mathrm{H}=2.07)$. Besides, the value of trophic diatom index (TDI) shows the change in status of eutrophic waters $(\mathrm{TDI}=52)$ become into the meso eutrophic (TDI=38). Similarly, based on the percentage of pollution tolerant values (\%PTV) there was decreasing the level of organic pollution from heavily organic pollution $(\mathrm{PTV}=93.3 \%$ ) become some organic pollution contribute to eutrophication with PTV 37.8\% (Kelly and Whitton 1995; Kelly 1998; Wu et al. 2014).

Based on the above illustration, it can be concluded that the planting of some local Hydromacrophytes in three phytoremediation ponds which plant coverage achieved 75$80 \%$ of the pond area through a continuous culture system with water discharge about $0.3 \mathrm{~L} /$ seconds has been able to improve the quality of water in irrigation canals. It was reflected from decreasing the concentration of water conductivity, TSS, nitrate and orthophosphate significantly in pond 3 and the change status from heavily polluted in the pond 1 to moderately polluted in the pond 3 (based on diatom Shannon Wiener diversity index), from eutrophic waters become meso-eutrophic (based on TDI) and from heavily organic pollution become some organic pollution contribute to eutrophication (based on \%PTV).

\section{ACKNOWLEDGEMENTS}

I thank to Mr. Pudji Raharjo for permission to use the pond. I thank the head of the Biology Department and Dean of Mathematics and Natural Sciences Faculty, Brawijaya University for their support of this research from project DPP/SPP 2015.

\section{REFERENCES}

Ayers RS, Westcot DW. 1994. Water Quality for Agriculture. FAO Irrigation and Drainage Paper 29. FAO, Rome.

Barko JW, Hardni DG, Matthews MS. 1982. Growth and morphology of submerged macrophytes in relation to light and temperature. Can J Bot 60: 877-887.

Chaudhry Q, Schroder P, Werck-Reichhart D, Grajek W, Marecik R. 2002. Prospects and limitations of phytoremediation for the removal of persistent pesticides in the environment. Environ Sci Pollut Res 9: 4-17.

Chen D, Lu J, Wang H, Shen Y, Kimberley MO. 2010. Seasonal variations of nitrogen and phosphorus retention in an agricultural drainage river in East China. Environ Sci Pollut Res 17: 312-320.

Clesceri LS, Greenberg AE, Eaton AD. 1998. Standard Methods for the Examination of Water and Waste Water. $20^{\text {th }}$ Ed. American Public Health Association APHA, Washington.

Edmondson WT. 1959. Freshwater Biology. 2nd ed. John Wiley and Sons Inc, New York.

EPA. 2000. Introduction to Phytoremediation. Office of Research and Development, U.S. Environmental Protection Agency, Cincinnati, Ohio.

Etim EE. 2012. Phytoremediation and its mechanisms; a review. Int J Environ Bioenergy 2 (3): 120-136.

Guntenspergen GR, Stearn F, Kadlec JA. 1989. Wetland vegetation. In: Hammer DA (eds) Constructed Wetlands for Wastewater Treatment, Municipal, Industrial and Agricultural. Lewis Publishers, Michigan.

Herbst DB, Blinn DW. 2007. Preliminary Index of Biological Integrity (IBI) for Periphyton in the Eastern Sierra Nevada. [California Research Report]. California University, California.

Ivansyah K, Retnaningdyah C. 2013. The potential of local hydromacrophytes for improvement of irrigation water quality polluted by residue of NPK fertilizer with batch system culture. Biotropika 1 (3): 80-84. [Indonesian]. 
Jayaweera MW, Kasturiarachchi JC. 2004. Removal of nitrogen and phosphorus from industrial wastewater by phytoremediation using water hyacinth (Eichhornia crassipes (Mart.) Solms). Water Sci Tech 50: 217-225.

John J. 1995. Biological monitoring of water quality of rivers, the ideal bioindicators. Workshop on Efforts Towards Increasing the Self Purification of Brantas River. Brawijaya University, Malang, Indonesia, 17-19 July 1995.

Kelly MG. 1998. Use of the trophic diatom index to monitor eutrophication in rivers. Water Res 32 (1): 236-242.

Kelly MG, Whitton BA.1995. The trophic diatom index: a new index for monitoring eutrophication in rivers. J of Appl Phyco 7: 433-444.

Marcus S, Kŏhler J. 2006. A simple model of phosphorus retention evoked by submerged macrophytes in lowland rivers. Hydrobiology 563: 521-525.

Mbao E, Kitaka N, Oduor SO, Kipkemboi J. 2013. Periphyton as inorganic pollution indicators in Nyangores tributary of the Mara River in Kenya. Int J of Fish and Aq Sci 2 (4): 81-93.

Onyema IC. 2013. Phytoplankton bio-indicators of water quality situations in the Iyagbe lagoon, south-western Nigeria. Acta SATECH 4 (2): 93-107.

Panagopoulos I, Mimikou M, Kapetanaki M. 2007. Estimation of nitrogen and phosphorus losses to surface water and groundwater through the implementation of the SWAT model for Norwegian soils. J Soils Sediments 7: 223-231.

Prahardika BA, Retnaningdyah C, Suharjono. 2013. The control of Microcystis spp. bloom by combining indigenous denitrifying bacteria from Sutami reservoir with Fimbristylis globulosa and Vetiveria zizanoides. J Trop Life Sci 3 (1): 52-57.

Prescott GW. 1978. How to Know the Fresh Water Algae. 3rd ed. Wm C Brown Company Publisher, Iowa.

Retnaningdyah C, Marwati U, Suharjono, Ajijah N, Marjono, Soegianto A, Irawan B. 2009. The potentially of nitrate reducing bacteria formulation isolated from Sutami reservoir Malang in inhibiting the growth of Microcystis. Berkala Penelitian Hayati 14: 209-217. [Indonesian].

Retnaningyah C, Suharjono, 2010. Optimizing of Bioremediation Techniques from Water in Sutami Reservoir Malang as a Result of Phosphate and Nitrate Contamination and Blooming of Microcystis using Microbes and Hydromacrophytes. [National Competitive Grant Research Reports]. Brawijaya University, Malang. [Indonesian].

Retnaningyah C, Suharjono, Budiman, Purnomo. 2012. Control of Microcystis growth by Azolla sp. in combination with aerobic denitrifying bacteria indigenous from Indonesia reservoir. Malaysia
International Biological Symposium ( $i$-SIMBIOMAS), Kuala Lumpur, Malaysia, 11-12 July 2012.

Retnaningdyah C, Arisoesilaningsih E. 2013. Ecological significance of irrigation channel riparian to improve benthic macroinvertebrate diversity. International Conference on Global Resource Conservation (ICGRC), Malang, Indonesia. 7-8 February 2013.

Roubeix V, Mazzella N, Schouler L, Fauvelle V, Morin S. 2011. Variations of periphytic diatom sensitivity to the herbicide diuron and relation to species distribution in a contamination gradient: implications for biomonitoring. J Environ Monit 13: 1768-1774.

Saunders DL, Kalff J. 2001. Nitrogen retention in wetlands, lakes and rivers. Hydrobiology 443: 205-212.

Singh UB, Ahluwalia AS, Sharma C, Jindal R, Thakur RK. 2013. Planktonic indicators: a promising tool for monitoring water quality (early-warning signals). Ecol Environ Conserv 19 (3): 793-800.

Sundari AS, Retnaningdyah C, Suharjono. 2013. The effectiveness of Scirpus grossus and Limnocharis flava as fitoremediation agents of nitrate-phosphate to prevent Microcystis blooming in fresh water ecosystem. J Trop Life Sci 3 (1): 28-33.

Sybil PS, Renée VS, Elizabeth WB, Richard BA, Gilles B, Robert WH, Bernhard M, Nico VB. 2002. Nitrogen retention in rivers: model development and application to watersheds in the Northeastern U.S.A. Biogeochemistry 57: 199-237.

Tan X, sheldon F, Bunn SE., Zhang Q. 2013. Using diatom indices for water quality assessment in a subtropical river, China. Environ Sci Pollut Res 20: 4164-4175.

Vidayanti V, Retnaningdyah C, Suharjono. 2012. The capability of Equisetum ramosissium and Typha angustifolia as phytoremediation agents to reduce nitrate-phosphate pollutants and prevent Microcystis blooming in fresh water ecosystem. J Trop Life Sci 2 (3): 126-131.

Wu N, Schmalz B, Fohrer N. 2014. Study Progress in riverine phytoplankton and its use as bio-Indicator-a review. Austin J Hydrol 1 (1): 9.

Xiang WE, Xiao Y, Rengel Z. 2009. Phytoremediation facilitates removal of nitrogen and phosphorus from eutrophicated water and release from sediment. Environ Monit Assess 157: 277-285.

Yang J, He Z, Yang Y, Stoffella P, Yang X, Banks D, Mishra S. 2007. Use of amendments to reduce leaching loss of phosphorus and other nutrients from a sandy soil in Florida. Environ Sci Pollut Res 14: 266269.

Yin F, Fu BJ, Mao RZ. 2007. Effects of nitrogen fertilizer application rates on nitrate nitrogen distribution in saline soil in the Hai River basin, China. J Soils Sed 7: 136-142. 